Agric. Biol. Chem., 42 (10), $1825 \sim 1831,1978$

\title{
Metabolism of 1-Aminocyclopropane-1-carboxylic Acid
}

\author{
Mamoru Honma and Tokuji Shimomura \\ Department of Agricultural Chemistry, Hokkaido University, \\ Sapporo, Japan
}

Received March 1, 1978

\begin{abstract}
Several microorganisms capable of utilizing 1-aminocyclopropane-1-carboxylate (ACPC) were isolated from soil. A bacterium which belongs to Pseudomonas accumulated cellular $\alpha$-aminobutyrate with consumption of ACPC and cells incubated with ACPC medium had the activity deaminating the substrate to form $\alpha$-ketobutyrate. An enzyme, ACPC deaminase, was highly purified and its molecular weight, substrate specificity and absorption spectrum were investigated. These results suggested that this enzyme was a pyridoxal 5 '-phosphate enzyme which has the molecular weight of 104000 and high specificity for ACPC, $K m=1.5 \mathrm{~mm}$. A yeast, Hansenula saturnus, is also capable of forming ACPC deaminase, which has a lower molecular weight, 69000 , and higher $\mathrm{Km}$ value, $2.6 \mathrm{~mm}$.
\end{abstract}

Detailed studies have been reported on two specific enzymes participating in metabolism of $\alpha$-dialkyl- $\alpha$-amino acids. Those are $\alpha$-aminoisobutyrate decomposing enzyme ${ }^{1,3)}$ (dialkylamino-acid decarboxylase (pyruvate), EC 4.1. 1.64) and $\alpha$-methylserine hydroxymethyltransferase, ${ }^{4)}$ (EC 2.1.2.7). The former as well as the latter is not active on 1-aminocyclopropane1-carboxylate ${ }^{3}$ (ACPC), one of $\alpha$-dialkyl- $\alpha$ amino acids, which was already isolated from cider apple and perry pear juices ${ }^{5)}$ and cow berry. ${ }^{6)}$ Burroughs $^{5 /}$ noted that ACPC was less readily assimilated by yeast than other amino acids, because it was found in the fermented perry as a major component of the remaining amino acids. Therefore, if some microorganisms are capable of utilizing ACPC, it is expected that the metabolism of this amino acid is dependent on a unique reaction.

Microorganisms that were isolated from soil with a medium containing ACPC as the sole source of nitrogen produced an enzyme which catalyzes ACPC deamination. This deamination proceeds together with opening of cyclcpropane ring to form $\alpha$-ketobutyric acid from ACPC. Experiments on the enzyme and the enzymatic reaction are described in this paper.

\section{METHODS}

Microorganisms and preparation of cell free extracts.
Several microorganisms utilizing ACPC as nitrogen source, among which bacteria and yeast were included, were isolated from soil. A bacterium used in experiments of this paper was a Gram-negative aerobic rod, motile with polar flagella, and grew well at slightly acidic $\mathrm{pH}(5 \sim 7)$ but not at $\mathrm{pH} 4.2$. Glucose was assimilated by respiratory metabolism and lactate was oxidized to carbonate. ${ }^{77}$ On the basis of these data, the bacterium was tentatively classified in the genus Pseudomonas ${ }^{9}$ and designated as Pseudomonas sp. ACP.

Shapes of the yeast cells were spherical or elliptical and its cells formed saturn-shaped ascospores. Nitrate was assimilated as its sole nitrogen source and external addition of vitamins was not effective for its growth. These data and results in assimilation of carbon compounds agreed with those of Hansenula saturnus (Klöcker) H. et P. Sydow var. saturnus. ${ }^{9)}$

The bacterium, Pseudomonas sp. ACP, was first cultured under shaking at $30^{\circ} \mathrm{C}$ for about $40 \mathrm{hr}$ in a medium being composed of $2 \%$ glucose, $0.5 \%$ peptone and $0.3 \%$ dried yeast extract. Cells harvested by centrifugation were washed with $0.1 \mathrm{M}$ potassium phosphate, pH 7.5 and further incubated in the second medium containing $1 \%$ sucrose and $0.1 \% \mathrm{ACPC}$ in the inorganic salt solution which is composed of $0.1 \%$ $\mathrm{KH}_{2} \mathrm{PO}_{4}, 0.1 \% \mathrm{~K}_{2} \mathrm{HPO}_{4}, 0.05 \% \mathrm{MgSO}_{4} \cdot 7 \mathrm{H}_{2} \mathrm{O}, 0.013 \%$ $\mathrm{CaCl}_{2} \cdot 2 \mathrm{H}_{2} \mathrm{O}$ and $0.0013 \% \mathrm{FeSO}_{4} \cdot 7 \mathrm{H}_{2} \mathrm{O}$. After the second incubation, cells were collected by centrifugation, suspended in $0.1 \mathrm{~m}$ potassium phosphate buffer, $\mathrm{pH} 7.5$, and ruptured by high-pressure extrusion method $^{10)}$ with French Press (Ohtake Works).

Yeast cells were collected by the same procedure as in the case of the bacterium. The first culture was carried out in a medium being composed of $3 \%$ sucrose, $0.2 \% \mathrm{KNO}_{3}$ and the inorganic salt solution and the second incubation was in a medium containing ACPC 
in place of $\mathrm{KNO}_{3}$ as the sole nitrogen source. The collected cells were suspended in $0.1 \mathrm{M}$ potassium phosphate buffer, $\mathrm{pH} 7.5$, and disrupted by high-pressure extrusion method ${ }^{10)}$ in Cell Disrupter (Stansted Fluid Power Ltd.).

Assay method. Intracellular amino acids of bacteria were extracted with $75 \%$ ethanol at $80^{\circ} \mathrm{C}$ for $5 \mathrm{~min}$. Amino acids were qualitatively investigated by means of cellulose thin-layer chromatography (sec-butanolformic acid-water, 75:15:10) and for the determination of ACPC, paper chromatography was done with the same solvent by the procedure described for $\alpha$-methylserine. ${ }^{11)}$ Carbonyl compound was detected by hydrazone formation ${ }^{12)}$ with 2,4-dinitrophenylhydrazine. Further, $\alpha$-ketobutyric acid was identified by several kinds of chromatography of free $\alpha$-keto acids or their derivatives, i.e., hydroxy acids or 2,4dinitrophenylhydrazones. The solution of hydroxy acids was prepared by reduction of each $\alpha$-keto acid with sodium borohydrate and gas-chromatography of 2,4-dinitrophenylhydrazone was performed by the procedure of Shimizu et al. ${ }^{13)} \alpha$-Ketobutyric acid was determined by the use of 2,4-dinitrophenylhydrazine according to the description of Hatfield et al. ${ }^{12\rangle}$ Formation of ammonia was measured by the indophenol method $^{14)}$ and consumption of oxygen was by the manometric method with a Warburg's apparatus.

$\alpha$-Aminoisobutyrate decomposing enzyme activity and $\mathrm{L}$-alanine- $\alpha$-ketobutyrate aminotransferase activity were assayed as described previously. ${ }^{16,18)}$

Miscellaneous. Aminohexyl-agarose was prepared by the method of Shaltiel et al., ${ }^{17)}$ from Sepharose $4 \mathrm{~B}$ and diaminohexane. ACPC was prepared according to the description of Burroughs.

\section{RESULTS}

Deamination of $A C P C$ by the enzyme from a bacterium, Pseudomonas sp. $A C P$

Bacterial cells obtained from the first culture were incubated in the second medium containing ACPC, and the media and alcoholic extracts of cells were used to examine alteration in amounts of amino acids with increasing time. Results of thin-layer chromatography are illustrated in Fig. 1, which shows decrease of ACPC in the medium and accumulation of $\alpha$ aminobutyric acid and isoleucine or leucine in cells. When an extract from cells grown on the second medium for $4.5 \mathrm{hr}$ was incubated with $30 \mathrm{~mm} \mathrm{ACPC}$ at $\mathrm{pH} 7.5$ (Table I), it was observed that decrease of ACPC resulted in

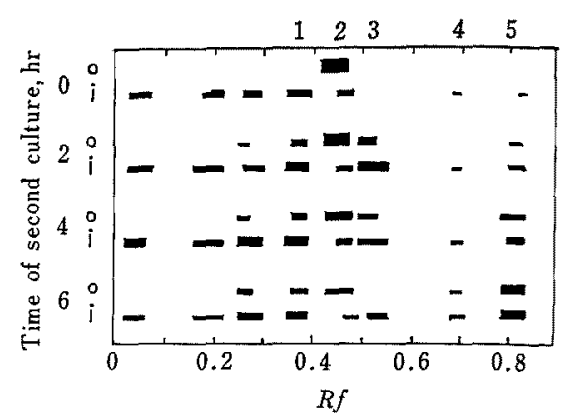

FIG. 1. Cellulose Thin-layer Chromatogram of Amino Acids in Media and in Extracts of Bacterial Cells.

Solvent: sec-butanol-formic acid-water (75:15:10), $o$, in medium; $i$, in cell extract; 1 , alanine; $2, \mathrm{ACPC}$; 3 , a-aminobutyric acid; 4 , valine; 5 , leucine or isoleucine.

Tabie I. Conversion of ACPC into a Carbonyl COMPOUND BY THE EXTRACT

Extract of cells grown on ACPC was incubated with $30 \mathrm{~mm} A C P C$ in phosphate buffer, $\mathrm{pH} 7.5$, at $30^{\circ} \mathrm{C}$.

\begin{tabular}{|c|c|c|c|}
\hline Condition & $\begin{array}{c}\text { Decrease } \\
\text { of } \\
\text { ACPC }\end{array}$ & $\begin{array}{c}\text { Formation } \\
\text { of } \alpha \text {-amino- } \\
\text { butyrate }\end{array}$ & $\begin{array}{l}\text { Formation } \\
\text { of carbonyl } \\
\text { compound }\end{array}$ \\
\hline Extract & + & + & + \\
\hline Dialyzed extract & + & \pm & + \\
\hline Dialyzed extract & & & \\
\hline $\begin{array}{l}\text { in nitrogen } \\
\text { atmosphere }\end{array}$ & + & - & + \\
\hline
\end{tabular}

formations of $\alpha$-aminobutyrate and carbonyl compound. In addition, the experiment with a dialyzed cell extract did not lead to the formation of $\alpha$-aminobutyrate in nitrogen atmosphere. Another product, carbonyl compound, was identified chromatographically to be $\alpha$-ketobutyric acid (Table II). Consequently, the extract seems to contain an enzyme which catalyzes the deamination of ACPC into $\alpha$ ketobutyrate without cofactor or oxygen. Table III shows the stoichiometrical evidence for enzymatic cleavage of ACPC into $\alpha$-ketobutyrate and ammonia. This experiment was done in a Warburg's apparatus with active fraction obtained by passing the cell extract through a Bio-Gel A-0.5 m column and did not exhibit participation of oxygen in the reaction. Therefore, the enzyme, ACPC deaminase, was determined by the following procedure. The 
TABLE II. Chromatography fOR THE IdentifiCATION OF THE CARBONYL COMPOUND

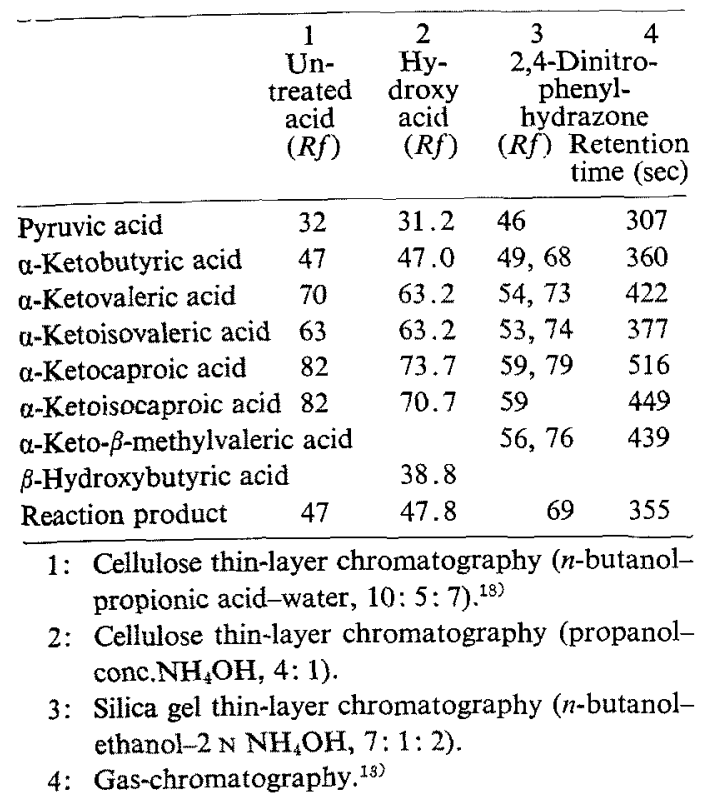

Table III. Stoichiometry of ACPC Deamination

The cell extract was passed through a Bio-Gel A$0.5 \mathrm{~m}$ column in advance and active fraction was incubated in a Warburg's apparatus with $10 \mu \mathrm{mol}$ of ACPC in $1.0 \mathrm{ml}$ of mixture, $\mathrm{pH} 7.5$, at $30^{\circ} \mathrm{C}$. After addition of $0.1 \mathrm{ml}$ of $3 \mathrm{~N} \mathrm{H}_{2} \mathrm{SO}_{4}$, an aliquot of the mixture was used for each assay.

\begin{tabular}{ccccc}
\hline $\begin{array}{c}\text { Incu- } \\
\text { bation } \\
\text { time } \\
(\mathrm{min})\end{array}$ & $\begin{array}{c}\text { Decrease } \\
\text { of } \\
\text { ACPC } \\
(\mu \mathrm{mol})\end{array}$ & $\begin{array}{c}\text { Formation Formation } \\
\text { of } \alpha \text {-keto- } \\
\text { butyrate } \\
(\mu \mathrm{mol})\end{array}$ & $\begin{array}{c}\text { Con- } \\
\text { of } \\
(\mu \mathrm{mol})\end{array}$ & $\begin{array}{c}\text { sumption } \\
\text { of oxygen } \\
(\mu \mathrm{mol})\end{array}$ \\
\hline 60 & 6.19 & 6.86 & 6.54 & 0.330 \\
120 & 8.28 & 8.36 & 8.25 & 0.320 \\
\hline
\end{tabular}

enzyme and $50 \mathrm{mM}$ ACPC were incubated in $0.2 \mathrm{ml}$ of $0.1 \mathrm{M}$ tris (hydroxymethyl) aminomethane buffer, $\mathrm{pH} 8.5$, at $30^{\circ} \mathrm{C}$. This $\mathrm{pH}$ of the buffer was chosen on the basis of a result in Fig. 2. The reaction was stopped by the addition of $1.8 \mathrm{ml}$ of $0.56 \mathrm{~N}$ hydrochloric acid. After addition of $0.3 \mathrm{ml}$ of $0.1 \% 2,4$-dinitrophenylhydrazine- $2 \mathrm{~N}$ hydrochloric acid solution, the mixture was kept at $30^{\circ} \mathrm{C}$ for $15 \mathrm{~min}$ and then $2 \mathrm{ml}$ of $2 \mathrm{~N}$ sodium hydroxide was added and absorbance at $540 \mathrm{~nm}$ was measured. One unit of the enzyme indicates the activity forming $1 \mu \mathrm{mol}$ of $a$-ketobutyrate per minute under these conditions.

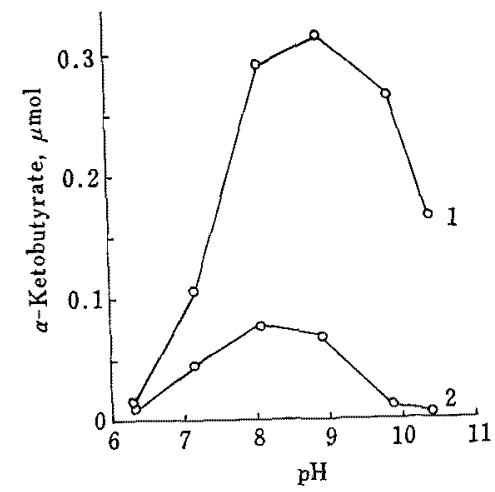

FIG. 2. Effect of pH on the Deamination of ACPC. Enzyme and $5 \mu \mathrm{mol}$ of ACPC were incubated in $0.2 \mathrm{ml}$ of $0.1 \mathrm{M}$ tris (hydroxymethyl) aminomethane$\mathrm{HCl}$ buffer, Each pH was adjusted by $\mathrm{KH}_{2} \mathrm{PO}_{4}$ in the lower $\mathrm{pH}$ range or $\mathrm{K}_{2} \mathrm{CO}_{8}$ and $\mathrm{KOH}$ in the higher $\mathrm{pH}$ range.

1 , enzyme from the bacteria; 2 , enzyme from the yeast.

Cell-free extracts were prepared from bacterial cells incubated in the second medium containing ACPC for indicated time and three enzyme activities were measured. Results in Table IV indicate the inducible formation of ACPC deaminase, little variation of L-alanine$\alpha$-ketobutyrate transaminase and formation of lower activity of $\alpha$-aminoisobutyrate decomposing enzyme. L-Alanine- $\alpha$-ketobutyrate transaminase seems to participate in the formation of $\alpha$-aminobutyric acid.

Table IV. Several Activities of Cell Extract

\begin{tabular}{|c|c|c|c|}
\hline \multirow{2}{*}{$\begin{array}{l}\text { Time of } \\
\text { second } \\
\text { culture } \\
\text { (hr) }\end{array}$} & \multicolumn{3}{|c|}{ Specific activity ( $\mathrm{u} / \mathrm{mg}$ of protein) } \\
\hline & $\begin{array}{r}\mathrm{ACPC} \\
\text { deamination }{ }^{a} \\
\operatorname{tran}^{2}\end{array}$ & $\begin{array}{l}\text { L-Alanine- } \\
\alpha \text {-ketobutyrate } \\
\text { nsamination de }\end{array}$ & $\begin{array}{l}\alpha \text {-Amino- } \\
\text { isobutyrate } \\
\text { composition }\end{array}$ \\
\hline 0 & 0.0009 & 0.0061 & 0.0000 \\
\hline 2 & 0.0128 & 0.0093 & 0.0006 \\
\hline 3.7 & 0.0494 & 0.0102 & 0.0039 \\
\hline 8 & 0.0438 & 0.0088 & 0.0032 \\
\hline
\end{tabular}

a ACPC deamination activity was measured as described in text.

\section{Purification of $A C P C$ deaminase from Pseudo-} monas sp. $A C P$

In the extract from bacterial cells, $37 \mathrm{~g}$, which were incubated in second medium for $4 \mathrm{hr}$, ethylenediaminetetraacetic acid and 2mercaptoethanol were dissolved to give each 
concentration of $1 \mathrm{~mm}$ as stabilizer. Potassium phosphate buffer, pH 7.5, containing $1 \mathrm{~mm}$ ethylenediaminetetraacetic acid and $1 \mathrm{~mm} \mathrm{2-}$ mercaptoethanol was used as solvent in all steps of procedure except for a final step. After solid ammonium sulfate, $13.68 \mathrm{~g}$, was dissolved in each $100 \mathrm{ml}$ of the extract, the mixture was stood for a few hours and the precipitate was removed by centrifugation. To the supernatant, ammonium sulfate was added up to concentration of $30.4 \mathrm{~g}$ per $100 \mathrm{ml}$ of the extract and the mixture was stood overnight. The precipitate obtained by centrifugation was dissolved in a small amount of $0.1 \mathrm{M}$ phosphate buffer and each one-third of the solution was passed through a Bio-Gel A- $0.5 \mathrm{~m}$ column $(2 \times 76 \mathrm{~cm})$. The active fractions were collected and dialyzed against $0.05 \mathrm{M}$ buffer.

The dialyzed enzyme solution was poured on DEAE-Sephadex A-50 column $(1.8 \times 15 \mathrm{~cm})$ equilibrated with $0.05 \mathrm{M}$ phosphate buffer and a linear gradient elution was done with the same buffer containing potassium chloride in the concentration range of zero to $0.4 \mathrm{M}$.

The active fractions were dialyzed against $0.05 \mathrm{M}$ phosphate buffer and adsorbed on aminohexyl-Sepharose column $(1.2 \times 11 \mathrm{~cm})$ equilibrated with $0.05 \mathrm{M}$ phosphate buffer and eluted with a linear gradient of potassium chloride concentration in the range of zero to $1 \mathrm{M}$.

Fractions of higher activity were concentrated by ultrafiltration and passed through a Sephadex G-150 column $(1.4 \times 94 \mathrm{~cm})$ washed with $0.1 \mathrm{M}$ phosphate buffer not containing the stabilizers. The purification procedure was summarized in Table V. Final preparation

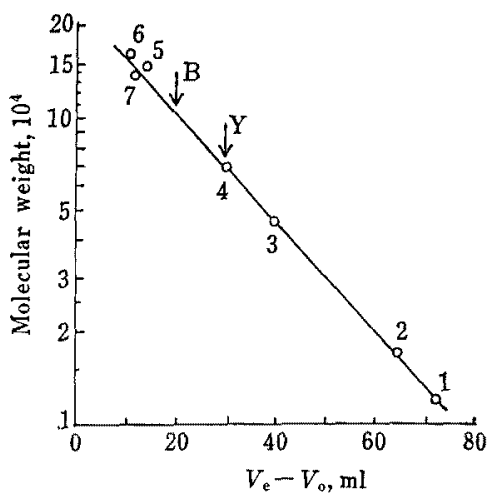

FIG. 3. Estimation of Molecular Weight of ACPC Deaminase by Sephadex G-150 Gel Filtration.

1, cytochrome c; 2, myoglobin; 3, egg albumin; 4 , bovine serum albumin; 5 , aldolase; 6 , human $\gamma$ globulin; $\mathrm{B}$, bacterial enzyme; $\mathrm{Y}$, yeast enzyme; 7 , bovine serum albumin dimer.

showed one band in disc electrophoresis by the system of Davis ${ }^{19)}$ and in gel electrofocusing $^{203}$ indicating isoelectric point of 5.1. Molecular weight of the enzyme protein was estimated to be 104,000 from Sephadex G-150 gel filtration (Fig. 3).

\section{Substrate specificity}

The purified enzyme, 0.018 unit, was incubated for $120 \mathrm{~min}$ with each following amino acid in a concentration of $50 \mathrm{~mm}$ except for cystathionine (5 mM) and tyrosine (25 mM). Enzymatic deamination of ACPC is considered to be a type of $\gamma$-elimination such as homoserine deamination. Nevertheless, ACPC deaminase showed a stringent substrate specificity and was inert to cystathionine, L-homoserine, L-methionine, L-threonine, L-serine, L-tryptophan, L-tyrosine, L-cysteine, L-aminobutyric acid and 1-aminocyclopentane-1-carboxylate.

Table V. Purification Procedure for ACPC Deaminase

\begin{tabular}{|c|c|c|c|c|c|}
\hline Step & Volume & $\begin{array}{c}\text { Total } \\
\text { protein }\end{array}$ & $\begin{array}{c}\text { Total } \\
\text { activity }\end{array}$ & $\begin{array}{l}\text { Specific } \\
\text { activity }\end{array}$ & Yield \\
\hline Cell extract & $440^{\mathrm{ml}}$ & 3806 & $78.5^{\mathrm{u}}$ & $\begin{array}{c}\mathrm{u} / \mathrm{mg} \\
0.0206\end{array}$ & 100 \\
\hline Ammonium sulfate & & & & & \\
\hline fractionation & 420 & 1500 & 60.7 & 0.0405 & 77.3 \\
\hline DEAE-Sephadex & 232 & 191 & 48.1 & 0.251 & 61.3 \\
\hline $\mathrm{NH}_{2}\left(\mathrm{CH}_{2}\right)_{8}$-Sepharose & 4.8 & 11.6 & 24.9 & 2.14 & 31.7 \\
\hline Sephadex G-150 & & 4.04 & 14.1 & 3.49 & 18.0 \\
\hline
\end{tabular}




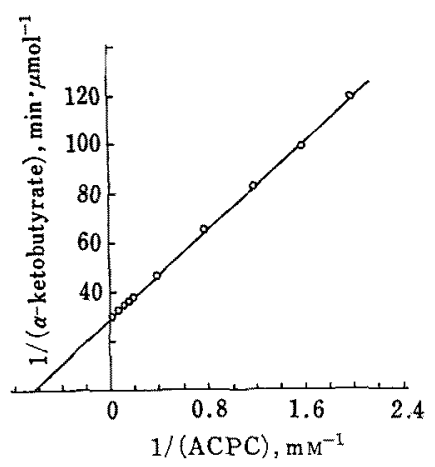

FIG. 4. Effect of ACPC Concentration on ACPC Deaminase Reaction.

ACPC deaminase, 0.035 unit, was incubated in $1.0 \mathrm{ml}$ of tris(hydroxymethyl)aminomethane buffer, $\mathrm{pH} 8.5$, and the reaction was stopped by the addition of $1 \mathrm{ml}$ of $1 \mathrm{~N} \mathrm{HCl}$.

Therefore, cyclopropane moiety in ACPC seems to be of importance for this deaminase reaction. A plot of reaction rate versus $\mathrm{ACPC}$ concentration showed a simple saturation curve and $K m$ value was calculated to be $1.5 \mathrm{~mm}$ (Fig. 4).

\section{Absorption spectrum of the enzyme}

The enzyme is active without any cofactor. However, the absorption spectrum of purified enzyme preparation (Fig. 5) has a maximum

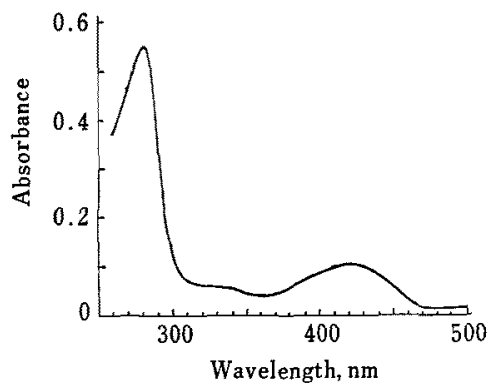

FIg. 5. Absorption Spectrum of Purified Enzyme at pH 7.5 . at about $420 \mathrm{~nm}$, indicating that the enzyme contains pyridoxal 5'-phosphate. In practice, the enzyme was inhibited by carbonyl reagents (Table VI). From Table VI, it is also indicated that the inhibited activity was not restored by the addition of pyridoxal 5'-phosphate and the intact enzyme preparation was not activated by this coenzyme. Accordingly, it is not clear whether the prosthetic group of ACPC deaminase is pyridoxal $5^{\prime}$-phosphate or not.

\section{TABle VI. Inhibition of ACPC DeAminase By Carbonyl Reagents}

Purified enzyme in $0.1 \mathrm{M}$ potassium phosphate, pH6.6, or in $0.1 \mathrm{M}$ tris(hydroxymethyl)aminomethane, pH 8.5, was treated with each reagent at $30^{\circ} \mathrm{C}$ for $30 \mathrm{~min}$. Each mixture was dialyzed against $0.1 \mathrm{M}$ tris(hydroxymethyl)aminomethane, $\mathrm{pH} 8.5$, and the remaining activity was measured in absence (1) or in presence (2) of pyridoxal 5'-phosphate. In latter case, enzyme solutions were preincubated with $0.1 \mathrm{~mm}$ pyridoxal $5^{\prime}$-phosphate at $30^{\circ} \mathrm{C}$ for $10 \mathrm{~min}$.

\begin{tabular}{|c|c|c|c|c|}
\hline \multicolumn{3}{|c|}{ Treatment } & \multicolumn{2}{|c|}{ Relative activity } \\
\hline Reagent & Concentrat & $\mathrm{pH}$ & 1 & 2 \\
\hline Control & - & 6.6 & 100 & 99 \\
\hline Control & - & 8.5 & 100 & 99 \\
\hline $\mathrm{NH}_{2} \mathrm{OH} \cdot \mathrm{HCl}$ & $1 \mathrm{~mm}$ & 8.5 & 12 & 11 \\
\hline \multicolumn{5}{|l|}{$\mathrm{C}_{0} \mathrm{H}_{5} \mathrm{NH}-\mathrm{NH}_{2}$. } \\
\hline $\mathrm{HCl}$ & 5 & 6.6 & 30 & 38 \\
\hline \multicolumn{5}{|c|}{$\mathrm{NH}_{2} \mathrm{CONH}-\mathrm{NH}_{2}$} \\
\hline $\mathrm{HCl}$ & 5 & 6.6 & 58 & 62 \\
\hline $\mathrm{KCN}$ & 1 & 8.5 & 33 & 30 \\
\hline $\mathrm{NaBH}_{*}$ & 1 & 8.5 & 16 & 15 \\
\hline
\end{tabular}

ACPC deaminase from a yeast, Hansenula saturnus

From a yeast which was isolated from soil by use of the ACPC medium, ACPC deaminase was partially purified by the same procedure as in the case of the bacterial enzyme except for omission of ammonium sulfate fractionation. The yeast enzyme was lower in the specific

Table VII. Purification Procedure for acPC Deaminase from Yeast

\begin{tabular}{|c|c|c|c|c|c|}
\hline Step & Volume & $\begin{array}{c}\text { Total } \\
\text { protein }\end{array}$ & $\begin{array}{c}\text { Total } \\
\text { activity }\end{array}$ & $\begin{array}{l}\text { Specific } \\
\text { activity }\end{array}$ & Yield \\
\hline Cell extract & $670^{\mathrm{ml}}$ & 1577 & $7.97^{\mathrm{u}}$ & $\begin{array}{r}\mathrm{u} / \mathrm{mg} \\
0.00504\end{array}$ & 100 \\
\hline DEAE-Sephadex & 210 & 69.3 & 3.84 & 0.0554 & 48 \\
\hline $\mathrm{NH}_{2}\left(\mathrm{CH}_{2}\right)_{\mathrm{B}}$-Sepharose & 9.8 & 5.21 & 1.83 & 0.351 & 23 \\
\hline Sephadex G-150 & & 0.978 & 1.35 & 1.38 & 17 \\
\hline
\end{tabular}


activity of cell extract and more labile than the bacterial enzyme. The purification procecure is shown in Table VII. The partially purified enzyme is similar to the bacterial enzyme with regard to optimum $\mathrm{pH}, 8.5$ (Fig. 2) and a stringent substrate specificity. But a lower value, 69000 , was estimated for its molecular weight from gel filtration (Fig. 3) and a higher $\mathrm{Km}$ value, $2.6 \mathrm{~mm}$, was calculated for ACPC.

\section{DISCUSSION}

Enzymatic opening reactions of cyclopropane ring were already observed in studies on cyclopropane carboxylate metabolism by Fusarium oxysporum, ${ }^{21)}$ metabolism of cyclopropane fatty acid by Tetrahymena pyriformis ${ }^{22}$ and metabolism of cyclopropyl sterols by higher plant. ${ }^{23)}$ In the first case, a reaction requires DL-carnitine to form an intermediate and in the second case, its reaction is not clear and another reaction is catalyzed by the microsomal fraction. As indicated in Tables I and III, a ring opening reaction in metabolism of ACPC was catalyzed without addition of cofactor and oxygen by the soluble enzyme and was regarded as $\gamma$-elimination by the deaminase, such as $\gamma$-cystathionase or methionase. Generally, elimination of $\gamma$-substituent from $\alpha$-amino acid requires the presence of $\alpha$ hydrogen atom. Since $\alpha$-hydrogen atom is absent in ACPC, it is considered that a cleavage of $\mathrm{C}-\mathrm{C}$ bond in cyclopropane ring leads to the same result as do the eliminations of both $\gamma$-substituent and $\alpha$-hydrogen in the $\gamma$-elimination of the other amino acids. Thus, ACPC deaminase seems to catalyze a special case of $\gamma$-elimination of amino acid. Therefore, it has a stringent substrate specificity for ACPC. Both enzymes from a bacterium and a yeast were not active to other amino acids tested than ACPC. Among these inert amino acids is included 1-aminocyclopentane-1-carboxylic acid. This finding shows the importance of cyclopropane ring in the substrate structure.

Purified ACPC deaminase from Pseudomonas sp. ACP seems to be pyridoxal 5'-phosphate protein whose molecular weight is about
104,000. Spectrum of the enzyme and inhibition by carbonyl reagents are consistent with the assumption of the participation of pyridoxal 5 -phosphate in ACPC deamination, but preincubation with this coenzyme did not result in increase of activity of the purified enzyme, nor restored the activity of the inhibited enzyme. Therefore, it seems that a prosthetic group is firmly bound to the enzyme protein provided that it is pyridoxal $5^{\prime}$-phosphate.

Acknowledgements. The authors wish to express their gratitude to Dr. T. Yoshida, Laboratory of Applied Microbiology, Hokkaido University, for his kind direction in classification of microorganisms.

\section{REFERENCES}

1) H. G. Aaslestad and A. D. Larson, J. Bacteriol., 88, 1296 (1964).

2) G. B. Bailey and W. B. Dempsey, Biochemistry, 6, 1526 (1967).

3) S. Tahara, M. Honma and T. Shimomura, Mem. Fac. Agric. Hokkaido Univ., 7, 12 (1969).

4) E. M. Wilson and E. E. Snell, J. Biol. Chem., 237, 3171 (1962).

5) L. F. Burroughs, Nature, 179, 360 (1957).

6) M. Vähätalo and A. I. Virtanen, Acta Chem. Scand., 11, 741 (1957).

7) J. L. Shimwell, J. G. Carr and M. E. Rhodes, J. Gen. Microbiol., 23, 283 (1960).

8) M. Doudoroff and N. J. Palleroni, "Bergey's Manual of Determinative Bacteriology," 8th edition, ed. by R.E. Buchanan and N.E. Gibbons, The Williams and Wilkins Co., Baltimore, 1974, p. 217.

9) L. J. Wickerham, "The Yeast, A Taxonomic Study," 2nd edition, ed. by J. Lodder, Northholland Publishing Company, Amsterdam. London, 1970, p. 299.

10) C.S. French and H. W. Milner, "Methods in Enzymology," Vol. 1, ed. by S. P. Colowick and N. O. Kaplan, Academic Press Inc., New York, 1955 , p. 64.

11) M. Honma and T. Shimomura, Agric. Biol. Chem., 40, 2105 (1976).

12) G. W. Hatfield and H. E. Umbarger, "Methods in Enzymology," Vol. 17 (B), ed. by M. Tabor and C. W. Tabor, Academic Press, New York, 1971, p. 561.

13) Y.Shimizu, S. Matsuto, Y. Ito and I. Okada, Nippon Nôgeikagaku Kaishi, 43, 211 (1969).

14) T. Nagata and K. Yagi, J. Biochem., 60, 219 (1966).

15) M. Honma and T. Shimomura, Agric. Biol. Chem., 
38, 953 (1974).

16) M. Honma, M. Ikeda and T. Shimomura, Agric. Biol. Chem., 36, 1661 (1972).

17) S. Shaltiel and Z. Er-El, Proc. Natl. Acad. Sci. U.S.A., 70, 778 (1973).

18) T. Wieland and E. Fisher, Naturwissenschaften, 36, 219 (1949).

19) B. J. Davis, Ann. New York Acad. Sci., 121, 404
(1964).

20) C. W. Wrigley, J. Chromatogr., 36, 362 (1968).

21) C. C. Guilbert and A. E. Chung, J. Biol. Chem, 249, 1026 (1974).

22) C. L. Tipton and N. M. Al-Shathir, ibid., 249, 886 (1974).

23) R. Heintz and P. Benveniste, ibid., 249, 4267 (1974). 